\title{
The Millenial Need of Broadband on Gunungkidul's Coastal Area for Sustainable Tourism Destination
}

\author{
Septiono Eko Bawono, Samsuharjo \\ \{septionoekobawono78@gmail.com ${ }^{1}$, kang_samsoe@ $@$ rocketmail.com $\left.{ }^{2}\right\}$ \\ Universitas Gunung Kidul, Jl. KH Agus Salim 170 Wonosari, Yogyakarta,Indonesia ${ }^{1}$
}

\begin{abstract}
Last 7 years, tourism at Gunungkidul has been visited tremendous tourists. The most favorite destination are beaches on coastal areas. This emerging destination is influenced by digital world largely. The research aims to determine the need of internet access on coastal areas. Identifying the 8Ps component's extended marketing mix, beaches as product serve the tourist satisfy. The research steps are identifying physical aspect (existing, infrastructure, amenities) and stake holder perception (tourist, expert community, local governement, and investor). The approach used mix method (qualitative and quantitative) to collect data (primary and secondary data). Collecting primary data by interviewing the key person. Validating the finding held focus group discussion at the end of research schedule. SWOT analysis is used to identify the stength, weakness, opprtunity and threat the coastal areas. The result shows the need of broadband to encourage sustainability tourism on coastal areas. The new branding will attract the tourists entireworld.
\end{abstract}

Keywords: Sustainable tourism destination, Gunungkidul coastal areas, Broadband.

\section{Introduction}

The area of Gunungkidul Regency has tourism potential as one of the assets of regional development. At last 7 years, the tourism sector has contributed significantly, to the Regency Revenue. It's about $\pm 7 \%$ of the regency revenue yearly. It is seem on the increase of the regency revenu on the tourism sector, which is Rp. 2,283,366,631.00 (2011), Rp. 3,464,755,588.00 (2012), Rp. 7,524,531,942,00 (2013), Rp. 15,420,475,427.00 (2014), and Rp. 20,980,945,431.00 (2015), Rp. 22,000,000,000.00 (2016), Rp. 27,000,000,000.00 (2017) (Culture and Tourism Potency of Gunungkidul Regency in 2017 and Tourism Office of Gunungkidul 2018). The revenue of this sector is dominated by coastal tourism revenue with the number of visitors reaching an average of $85.45 \%$ yearly. The total number of visitors is approximately 2 million tourists. This visitor includes domestic tourists and foreign tourists. As the most favorite destination, the southern coast of Gunungkidul has 60 beaches. These beaches are located in 3 Strategic Tourism Areas (Kawasan Strategis Pariwisata (KSP)) as stipulated in the Regional Tourism Master Plan (Rencana Induk Pariwisata Daerah (RIPPARDA)) of Gunungkidul Regency 2014-2025. KSP I covers 20 beaches, KSP II covers 15 beaches and KSP III covers 25 beaches. This development plan is also stipulated in the 2016-2021 Medium Term Regional Development Plan (Rencana Pembangunan Jangka Menengah Daerah (RPJMD)) in accordance with Gunungkidul District Government Regulation No. 4 of 2016. As the vision of regional development "Realizes Gunungkidul as a 
Leading and Cultured Tourism Destination Towards a Community of Competitive, Advanced, Independent and Prosperous 2021", the development of the tourism sector is a top priority.

Emphasizing on tourism development, the coastal areas is not adequate enough to serve the tourists. The development of the tourism sector needs to be supported by infrastructure, city scape, amenities which are not in adequate condition. The 60 coastal areas at Gunungkidul Regency, the beaches that has been managed by the local government consists of 5 beaches, they are Baron, Kukup, Drini, Krakal, and Sundak. The rest is managed independently by the community. Based on this condition, most coastal areas still need better and professional management. The needs should be done because this area includes the Geo Park Karst Area Global Network that certified by UNESCO since September 2012.

As we know, tourism sector attracts tourists, experts, community and investors. Tourists interest on enjoying the beaches, experts' interest on researches, community interest on developing the areas, and investors interest on investing assets. These phenomena are suffering the coastal areas. Huge numbers of tourists need more facilities. The coastal areas need more carrying capacities. The most coastal areas are managed by the community. The community initiatives produce sporadic development on several parts of the coastal areas. This sporadic development represents the lack of well management. As a result, the areas are facing lack of infrastructure and environmental degradation. Beside the degradation, appear conflicts on management issues. The conflict comes about seizing management of the beaches.

This study aims to identify the influence of extended marketing mix on place branding process. Determining the influence, this study collects the stake holder perception on tourism product satisfaction. Based on millennial marketing approach, it is consists of product, price, place, promotion, process, people, place lay out and planet (8Ps). This holistic awareness supports the place branding process that is held step by step (vision and action development, spatial and non spatial development, communication development).

\section{Research Problems}

To develope coastal areas, sustainable development approach is used around the world. Sustainability is used to brand and change an image of a place. This place branding process accordances extended marketing mix that emphasizing the 8Ps. Research main problem on developing Gunungkidul coastal areas are:

1. How is the tourism product satisfaction influenced by 8 Ps?

2. What is the main elements of 8Ps serve the tourists satisfy?

3. Is the satisfaction sustain?

4. Is there any system to develop place branding on coastal areas?

\section{Research Objectives}

Research aims to determine the main strategies of the Gunungkidul coastal areas development. The research objectives are:

1. To explore how the 8Ps satisfy the tourists.

2. To determine the main 8Ps elements based on stake holder's perception of coastal areas management.

3. To identify sustainability of tourists satisfaction. 
4. To improve the place branding development accordance the extended marketing mix use information system.

\section{Research Design}

The most important of tourism destination development is serving the tourist satisfy [1]. Magatef identify the characteristic and the elements of the tourist satisfaction based on marketing mix's elements. In order to develope best image of the city, it should define the place branding [2]. In millennial era, the place sholud be well known and well connected entireworld. To be well known and well connected, the city characters should be smart city, innovative city, connected city, sustainable city and authentic city [3]. Dealing with the satisfaction, tourism destination meets destination as a place and destination as a product. It shown as follow.

\begin{tabular}{|c|c|c|}
\hline $\begin{array}{l}\text { Extended Marketing } \\
\qquad \text { Mix } \\
\text { Product } \\
\text { Price } \\
\text { Place } \\
\text { Promotion } \\
\text { People } \\
\text { Process } \\
\text { Physical Lay Out } \\
\text { Planet }\end{array}$ & $\begin{array}{l}\text { Place Branding } \\
\text { Vision, Action Strategy } \\
\text { Image of the city } \\
\text { Spasial: } \\
\text { Lanscape } \\
\text { Infrastucture } \\
\text { Non spasial: } \\
\text { Structure } \\
\text { Behavior } \\
\text { Communication }\end{array}$ & $\begin{array}{l}\quad \text { Stake Holder } \\
\text { Satisfaction Perception } \\
\text { Tourist } \\
\text { Expert } \\
\text { Community } \\
\text { Local Govemment } \\
\text { Investor }\end{array}$ \\
\hline
\end{tabular}

Fig 1. Combination extended marketing mix and place components branding strategy

To determine the satisfaction perception, the research design combines the extended marketing mix elements and place branding strategy.

\section{Literatur Review}

Research aims to develope the sustainable system of the Gunungkidul coastal areas. Developing the sustainable system, following study show the mix elements.

\subsection{Sima Ghaleb Magatef, 2015 [1].}

The study aims to achieve objectives as: to identify the nature of inbound tourists coming to Jordan through studying the demographic profiles; to identify the impact of tourism marketing mix elements on the satisfaction of inbound tourists; to identify the characteristics and components of the Jordanian tourism product to establish a competitive tourism product that can satisfy inbound tourists, with concentration on the identity of the Jordanian tourist product; to identify the extent of satisfaction of the inbound tourists about prices of Tourism Products; to identify the promotional activities used in marketing Jordan as a tourist 
destination, and to identify the extent of their effectiveness in markets that export tourism to Jordan, and to identify how convenient they are to the tourism demand and to select the best promotional mix to be used from the tourist point of view; to identify the importance of distribution of the tourism product and the extent of inbound Tourist's Satisfaction with it; to select the most effective tourism marketing mix elements that will lead to the satisfaction of tourists; and to direct the decision makers of the tourism marketing strategies in Jordan and how they can use them to develop and improve tourism.

The result: The tourism destination should pay attention to all marketing mix elements to attract the greater tourists that will lead the tourists satisfaction.

\subsection{Florence Kamau, F. K. Waweru, Peter Lewa, A. J. Misiko, 2015 [4].}

The study encourages the tourism and hotel industry players to have a thorough understanding of the Kenyan domestic tourist so that they can have focused marketing strategies and marketing mixes targeted and packaged towards satisfying the needs of different market segments.

Result: All the marketing mix elements are important and must be well managed and implemented to ensure success.

\subsection{Sherine El Sakka, 2016 [5].}

The study explores the city applied to brand itself as a sustainable city and how good branding could assist making city desirable.

Result: The place branding is a way to promote sustainable initiative; it has potential as a leading tool for cities in developing countries.

\subsection{Sergejs Volvenkins and Martin Danusevics, 2011 [6].}

The study determines the degree of the use of internet and IT by Latvian Small and Medium Enterprizes.

Result: The Latvian Small and Medium Enterprizes are well presented on the internet.

\subsection{Ronggang Zhou, Patrick S. W. Fong, Peking Tan, 2014 [7].}

The study aims to investigate Internet usage and to determine whether active Internet use is a marker for low or high levels of leisure time activities.

Result: Internet use is one of very common leisure activities in Chinese citizens, and age, gender, income, and education are the key factors affecting Internet access.

\subsection{Paul Lapointe, 2016 [8].}

The study utilizes new data available as a result of the American Recovery and Reinvestment Act to examine the relationship between employment growth and access to fiber internet, currently seen as the gold standard of internet connections in terms of speed and reliability.

Result: There is positive relationship providesevidence to policy makers that promoting access to fiber internet is a viable economic development approach. 


\section{Data Collection}

\subsection{Deep Interview}

Interviewing the stakeholder (tourist, expert, community, local governement, and investor) to identify the tourism destination satisfaction as follow:

Table l. Stakeholder Satisfaction Perception according to Marketing Mix Elements

\begin{tabular}{|c|c|c|c|c|c|c|c|c|c|c|}
\hline \multirow[t]{2}{*}{ Element } & \multicolumn{2}{|c|}{ Tourist } & \multicolumn{2}{|c|}{ Expert } & \multicolumn{2}{|c|}{$\begin{array}{l}\text { Local } \\
\text { Community }\end{array}$} & \multicolumn{2}{|c|}{$\begin{array}{c}\text { Local } \\
\text { Government }\end{array}$} & \multicolumn{2}{|c|}{ Investor } \\
\hline & $(-)$ & $(+)$ & $(-)$ & $(+)$ & $(-)$ & $(+)$ & $(-)$ & $(+)$ & $(-)$ & $(+)$ \\
\hline Product & - & $\sqrt{1}$ & - & $\sqrt{1}$ & - & $\sqrt{1}$ & - & $\sqrt{1}$ & - & $\sqrt{ }$ \\
\hline Price & - & $\sqrt{ }$ & - & $\sqrt{ }$ & - & $\sqrt{ }$ & - & $\sqrt{ }$ & - & $\sqrt{ }$ \\
\hline Place & - & $\sqrt{ }$ & - & $\sqrt{ }$ & - & $\sqrt{ }$ & - & $\sqrt{ }$ & - & $\sqrt{ }$ \\
\hline Promotion & - & $\sqrt{ }$ & - & $\sqrt{ }$ & - & $\sqrt{ }$ & - & $\sqrt{ }$ & - & $\sqrt{ }$ \\
\hline People & - & $\sqrt{ }$ & - & $\sqrt{ }$ & - & $\sqrt{ }$ & - & $\sqrt{ }$ & - & $\sqrt{ }$ \\
\hline Process & - & $\sqrt{ }$ & - & $\sqrt{ }$ & - & $\sqrt{ }$ & - & $\sqrt{ }$ & - & $\sqrt{ }$ \\
\hline Physical Lay Out & - & $\sqrt{ }$ & - & $\sqrt{ }$ & - & $\sqrt{ }$ & - & $\sqrt{ }$ & - & $\sqrt{ }$ \\
\hline Planet & - & $\sqrt{ }$ & - & $\sqrt{ }$ & - & $\sqrt{ }$ & - & $\sqrt{ }$ & - & $\sqrt{ }$ \\
\hline
\end{tabular}

The stake holders consists of 10 domestic tourists, 1 foreign tourist, 1 expert, 2 representatives of local government, 2 members of local community, and 1 investor.

\subsection{Field Observation}

Interviewing the stakeholder (tourist, expert, community, local governement, and investor) to identify the tourism destination satisfaction as follow:

Table 2. Places Branding of the Beaches on Gunungkidul Coastal Areas Identification

\begin{tabular}{|c|c|c|c|c|c|c|c|c|c|c|c|c|c|c|}
\hline \multirow{3}{*}{ Beach } & \multirow{2}{*}{\multicolumn{2}{|c|}{$\begin{array}{l}\text { Vision, } \\
\text { Action }\end{array}$}} & \multicolumn{4}{|c|}{ Spatial } & \multicolumn{4}{|c|}{ Non Spatial } & \multicolumn{4}{|c|}{ Brand Communication } \\
\hline & & & \multicolumn{2}{|c|}{ Landscape } & \multicolumn{2}{|c|}{ Infrastructure } & \multicolumn{2}{|c|}{ Structure } & \multicolumn{2}{|c|}{ Behavior } & \multicolumn{2}{|c|}{ On Line } & \multicolumn{2}{|c|}{$\begin{array}{l}\text { Mouth to } \\
\text { Mouth }\end{array}$} \\
\hline & $(-)$ & $(+)$ & $(-)$ & $(+)$ & $(-)$ & $(+)$ & $(-)$ & $(+)$ & $(-)$ & $(+)$ & $(-)$ & $(+)$ & $(-)$ & $(+)$ \\
\hline Gesing & $\sqrt{1}$ & - & - & $\sqrt{1}$ & $\sqrt{1}$ & - & - & $\sqrt{ }$ & - & $\sqrt{1}$ & $\sqrt{1}$ & - & - & $\sqrt{1}$ \\
\hline Ngobaran & $\sqrt{ }$ & - & - & $\sqrt{ }$ & $\sqrt{ }$ & - & - & $\sqrt{ }$ & - & $\sqrt{ }$ & $\sqrt{ }$ & - & - & $\sqrt{ }$ \\
\hline Baron & $\sqrt{ }$ & - & - & $\sqrt{ }$ & $\sqrt{ }$ & - & - & $\sqrt{ }$ & - & $\sqrt{ }$ & $\sqrt{ }$ & - & - & $\sqrt{ }$ \\
\hline Kukup & $\sqrt{ }$ & - & - & $\sqrt{ }$ & $\sqrt{ }$ & - & - & $\sqrt{ }$ & - & $\sqrt{ }$ & $\sqrt{ }$ & - & - & $\sqrt{ }$ \\
\hline Sepanjang & $\sqrt{ }$ & - & - & $\sqrt{ }$ & $\sqrt{ }$ & - & - & $\sqrt{ }$ & - & $\sqrt{ }$ & $\sqrt{ }$ & - & - & $\sqrt{ }$ \\
\hline Watukodok & $\sqrt{ }$ & - & - & $\sqrt{ }$ & $\sqrt{ }$ & - & - & $\sqrt{ }$ & - & $\sqrt{ }$ & $\sqrt{ }$ & - & - & $\sqrt{ }$ \\
\hline Drini & - & $\sqrt{ }$ & - & $\sqrt{ }$ & $\sqrt{ }$ & - & - & $\sqrt{ }$ & - & $\sqrt{ }$ & $\sqrt{ }$ & - & - & $\sqrt{ }$ \\
\hline Krakal & $\sqrt{ }$ & - & - & $\sqrt{ }$ & $\sqrt{ }$ & - & - & $\sqrt{ }$ & - & $\sqrt{ }$ & $\sqrt{ }$ & - & - & $\sqrt{ }$ \\
\hline Sadranan & $\sqrt{ }$ & - & - & $\sqrt{ }$ & $\sqrt{ }$ & - & - & $\sqrt{ }$ & - & $\sqrt{ }$ & $\sqrt{ }$ & - & - & $\sqrt{ }$ \\
\hline Indrayanti & - & $\sqrt{ }$ & - & $\sqrt{ }$ & $\sqrt{ }$ & - & - & $\sqrt{ }$ & - & $\sqrt{ }$ & - & $\sqrt{ }$ & - & $\sqrt{ }$ \\
\hline Sundak & $\sqrt{ }$ & - & - & $\sqrt{ }$ & $\sqrt{ }$ & - & - & $\sqrt{ }$ & - & $\sqrt{ }$ & $\sqrt{ }$ & - & - & $\sqrt{ }$ \\
\hline Timang & $\sqrt{ }$ & - & - & $\sqrt{ }$ & $\sqrt{ }$ & - & - & $\sqrt{ }$ & - & $\sqrt{ }$ & - & $\sqrt{ }$ & - & $\sqrt{ }$ \\
\hline Nglambor & $\sqrt{ }$ & - & - & $\sqrt{ }$ & $\sqrt{ }$ & - & - & $\sqrt{ }$ & - & $\sqrt{ }$ & $\sqrt{ }$ & - & - & $\sqrt{ }$ \\
\hline Siung & $\sqrt{ }$ & - & - & $\sqrt{ }$ & $\sqrt{ }$ & - & - & $\sqrt{ }$ & - & $\sqrt{ }$ & $\sqrt{ }$ & - & - & $\sqrt{ }$ \\
\hline Wediombo & $\sqrt{ }$ & - & - & $\sqrt{ }$ & $\sqrt{ }$ & - & - & $\sqrt{ }$ & - & $\sqrt{ }$ & $\sqrt{ }$ & - & - & $\sqrt{ }$ \\
\hline
\end{tabular}

Gunungkidul Coastal Areas have 60 beaches. To identify the place branding of the beach, the study uses purposive random sample and identify 15 the most popular beaches. 


\subsection{Focus Group Discussion}

Focus Group Discussion (FGD) is held to validate the finding of the research as follow: Table 3. Main Issues on Developing Coastal Areas during FGD

\begin{tabular}{|c|c|c|c|c|c|c|c|c|c|c|c|c|}
\hline \multirow[b]{2}{*}{ Community } & \multicolumn{2}{|c|}{ Tourism Image } & \multicolumn{2}{|c|}{ Infrastructure } & \multicolumn{2}{|c|}{ Structure } & \multicolumn{2}{|c|}{ Behavior } & \multicolumn{2}{|c|}{ Broadband } & \multicolumn{2}{|c|}{ Participation } \\
\hline & $(-)$ & $(+)$ & $(-)$ & $(+)$ & $(-)$ & $(+)$ & $(-)$ & $(+)$ & $(-)$ & $(+)$ & $(-)$ & $(+)$ \\
\hline Officer & - & $\sqrt{1}$ & $\sqrt{1}$ & - & - & $\sqrt{1}$ & $\sqrt{1}$ & - & $\sqrt{1}$ & - & - & $\sqrt{ }$ \\
\hline Active Member & - & $\sqrt{ }$ & $\sqrt{ }$ & - & - & $\sqrt{ }$ & - & $\sqrt{ }$ & $\sqrt{ }$ & - & - & $\sqrt{ }$ \\
\hline Pasive Member & - & $\sqrt{ }$ & $\sqrt{ }$ & - & - & $\sqrt{ }$ & - & $\sqrt{ }$ & $\sqrt{ }$ & - & - & $\sqrt{ }$ \\
\hline
\end{tabular}

The community consists of 150 members of local community: 1 coordinator; 75 active members and 75 pasive members.

\section{SWOT Analysis}

Based on 6 main issues during FGD, SWOT Analysis points them to answer the research question above. They are: tourism image; lack infrastructure; traditional organization; behavior improvement; broadband need; and degree of participation.

Table 4. SWOT Analysis of the Main Issues on Developing Gunungkidul Coastal Areas

\begin{tabular}{|c|c|c|}
\hline External Aspect & $\begin{array}{c}\text { Strength } \\
- \text { Strong tourism image } \\
\text { - Strong traditional } \\
\text { organization } \\
\text { - Strong participation }\end{array}$ & $\begin{array}{l}\text { Weaknes } \\
\text { - Lack of infrastructure } \\
\text { - Lack broadband } \\
\text { - Behavior improvement }\end{array}$ \\
\hline $\begin{array}{l}\text { Opportunity } \\
\text { - Investment }\end{array}$ & $\begin{array}{l}\text { Developing strong } \\
\text { image of coastal area }\end{array}$ & $\begin{array}{ll}\text { - Developing } & \text { coastal } \\
\text { areas as } & \text { digital } \\
\text { destination } & \end{array}$ \\
\hline $\begin{array}{l}\text { Threat } \\
-\quad \text { Ownership conflict }\end{array}$ & $\begin{array}{l}\text { Developing } \\
\text { collaborative } \\
\text { management }\end{array}$ & $\begin{array}{l}\text { Developing local } \\
\text { system management }\end{array}$ \\
\hline
\end{tabular}

According to SWOT Analysis above, research question is answered as follow:

1. The stake holders stated that 8Ps influence the tourism product satisfaction.

2. All elements contribute degree of satisfaction evenly.

3. Yes it is. Well management will sustain the satisfaction as manage as systemic.

4. Yes there is. Developing management system will contribute the coastal areas brand. And there is possibility developing integrated infrastructure management system based on IT.

\section{Conclusion}

Research aims to determine the main strategies of the Gunungkidul coastal areas development. The SWOT Analysis shows the places evidence have strong values. It is usefull to improve the weakness. Even there is a conflict potency, they have opportunities to develope 
the coastal areas as authentic tourism products and emerge the product globally. The analysis shows that there are strategies:

1. A competitive advantage: strengthening the image of coastal area.

2. A defensive capability: collaborating well management.

3. A reorientation need: developing digital destination.

4. A vulnerability: developing local system management.

Strengthening the strategies above, in millennial era they should supported by sub infrastructure "broadband'.

\section{References}

[1] S. G. Magatef, "The Impact of Tourism Marketing Mix Elements on the Satisfaction of Inbound Tourists to Jordan,” Int. J. Bus. Soc. Sci., pp. 41-58, 2015.

[2] M. Kavaratzis, "Branding the City through Culture and Entertainment. Urban and Regional Studies Institute.”.

[3] J. . Mendes, O Futuro das Cidades. Minerva Coimbra, 2012.

[4] D. A. J. M. Florence Kamau, Professor F. K. Waweru, Professor Peter Lewa, "The Effects of the Marketing Mix on Choice of Tourist Accommodation by Domestic Tourists in Kenya.," Int. J. Nov. Res. Mark. Manag. Econ., pp. 25-34, 2015.

[5] S. El Sakka, "Sustainablity as an Effective Tool for a Place Branding: An Application on El Gouna City, Egypt.," Int. J. Environ. Sci. Dev., pp. 861-866, 2016.

[6] S. Volvenkins and M. Danusevics, "The Use of Internet and It by Small and Medium Sized Enterprises,” Int. J. Arts Sci., pp. 443-452, 2011.

[7] P. T. Ronggang Zhou, Patrick S. W. Fong, Internet Use and Its Impact on Engagement in Leisure Activities in China. Plos One, 2014.

[8] P. Lapointe, "Does Speed Matter? The Employment Impact of Increasing Access to Fiber Internet," J. Washingt. Acad. Sci., pp. 9-28, 2015. 